\title{
A Review on Measures for Prevention of Community Transmission of COVID-19
}

\author{
Srishti Choudhary \\ Jawaharlal Nehru Medical College, Datta Meghe Institute Of Medical Sciences Wardha \\ Corresponding author email: choudharysrishti@gmail.com
}

\section{ABSTRACT}

The COVID-19 pandemic originated in Wuhan city of China and invaded the whole world of few months it became a major disease burden for the whole world within a few weeks. The disease is still not fully understood and created a worldwide panic due to non-availability of definitive treatment option. In spite of intense rigorous research, novel diagnostic approaches, latest drug trials, prevention remains the mainstay to avoid any health complications and limit the spread. Strategies were designed by healthcare experts to create awareness to prevent transmission. Quarantine and isolation deteriorates mental health in certain individuals it causes irritation, depression , anxiety and their mental health problems thus proper counselling should be done for such individuals. It also causes financial loss and there is a lot of social stigma surrounding it. Managing mental health plays a key role during isolation or during quarantine. Social media has also been essential in creating awareness related to this pandemic. Apps like Arogya Setu app used in India enhances safety of the population, gives proper data about high risk areas. Also many apps have been used for hospital bed allocation and online drug supply during this pandemic This review article focussed on transmission and preventive measures for COVID-19.

KEY WORDS: PREVENTION, PERSONAL HYGIENE, SOCIAL DISTANCING, LOCKDOWN, COVID-19, MASK.

\section{INTRODUCTION}

Coronavirus is an enveloped, single stranded RNA virus that belongs to coronavirus family and nidovirales order. Earlier the causative agent was named "novel corona virus 2019" (2019-nCoV) by the WHO, later it has been renamed to "severe acute respiratory syndrome coronavirus 2" (SARS-CoV-2) (Fan y, et. al. 2019). The spread of this infection is via person to person or through droplets when an infected person sneezes. It is also thought to be spread through fomites (objects that have droplet particles on them) or through inhaling aerosol containing the virus. till now other modes of spread is unknown. asymptomatic carriers of corona virus infection

Biosc Biotech Res Comm P-ISSN: 0974-6455 E-ISSN: 2321-4007

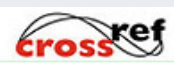

Identifiers and Pagination

Year: 2021 Vol: 14 No (6) Special Issue

Pages: 214-219

This is an open access article under Creative

Commons License Attribn 4.0 Intl (CC-BY).

DOI: http://dx.doi.org/10.21786/bbrc/14.6.45 can also transmit this disease. Early screening among high risk individuals, diagnosis, efficient treatment, isolation of the infected will limit the spread. it has been seen that international travellers have a higher chance of contracting the disease. The most important strategy to decrease the spread includes frequent hand washing with soap or alcohol based sanitizers, practicing respiratory hygiene using N95, cloth masks, surgical masks have been proved to limit the disease. authorities should put a limit on overcrowding. all the events that require overcrowding of people should be avoided.Countries that failed to do so saw a rise in the number of covid cases exponentially.

Corona virus infection may cause a variety of symptoms ranging from sore throat, headache, fever, body pain, flu like symptoms, diarrhea to even more severe problems like pneumonia leading to death by respiratory failure.

\section{Modes of Transmission}

1. Human To Animal Transmission- it is unclear how this outbreak originates. It is thought to be a zoonotic infection ie transmission of coronavirus from animals to humans. Studies show that the bat coronavirus genome is

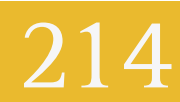


similar to the genome of the coronavirus in this current pandemic suggesting bats to be the reservoir of this acute human infection. Wuhan market bats are thought to be the source of infection.

\section{Human to human transmission-}

a) Direct spread- person to person spread via contact. Direct contact of the virus through mouth, eyes and nose. This happens via fomites (Belser J.A.,et. al. 2013).

b) Aerosol- virus can survive in the aerosol as well as infect people upto $3 \mathrm{hrs}$. It is also seen that the virus survives on surfaces like plastic or stainless steel for upto 48 hrs (Doremalen N.,et. al. 2020).

c) Droplet - a corona virus patient sneezes the virus as droplets in the air if these droplets are inhaled by healthy individuals it causes infection.

d) Feco oral- this mode is not clearly undersood. It is thought to be due to increased ACE2 receptors in the glandular epithelium of gastric mucosa, colonic and ieal. To which the virus attaches and replicates causing infection (Yeo C.,et. al. 2020).

Hand Sanitation in Prevention of Transmission of Covid Infection: Sanitizers that are alcohol based are very cost effective way to prevent transmission of the disease. Thi is most helpful for preventing fomite spread. Mechanism of action of alcohol - alcohol destroys the virus by denaturing proteins. It destroys the proteins in the enveloped viruses and inactivates it. Alcohol based hand rubs that contain 60\% ethanol has been approved for use. Ethanol(80\% v/v)and isopropyl alcohol (75\% v/v) are recommended (Cascella M.,et. al. 2020).
"My 5 moments of hand hygiene" given by WHO -
1. before touching a patient
2. before clean or aseptic procedures
3. after body fluid exposure or risk
4. after touching a patient
5. after touching a patients surrounding

Hand sanitizers come in many forms, as gel, foam, spray, wipe and cream. Side effects of overusing and careless use of alcohol based sanitizers include fire accidents , skin irritation, contact dermatitis etc

Other Compounds Used As Sanitizer- have certain antiseptic properties.includes - chlorhexidine, chloroxylenol, triclosan, iodine / iodophors, quaternary ammonium compounds, chloroxylenol (Van Asselt A.J.,2005).

Use of Masks in Prevenion of Covid 19: The infectivity of SARS COV 2 is very high. The R0 (basic reproductive number) is 1.4 to 3.9 . to prevent droplet spread of the virus face masks should be used covering both nose and mouth. It provides a mechanical barrier in transmission of infection. Could be disposable surgical masks, cloth masks, respirators with or without valve. Mask not only helps in preventing the inhalation of the virus it also provides lesser hand to face contact. In certain countries like India mask use has been aide compulsory for going out in public. A fine is imposed on people who don't follow it.

\begin{tabular}{|c|c|c|}
\hline Chemical group & Examples & Mechanism of action \\
\hline alcohol & Ethanol, isoprpanol & $\begin{array}{l}\text { Denatures the proteins } \\
\text { in the cell membrane }\end{array}$ \\
\hline Iodine compounds & Povidone iodine & $\begin{array}{l}\text { Iodide penetrates } \\
\text { cells attacks viral proteins, } \\
\text { fatty acids and nucleotides }\end{array}$ \\
\hline Chlorine compounds & $\begin{array}{c}\text { Hypochlorites (ClO-) } \\
\text { Chlorine dioxide } \\
\text { Chloramines-t trihydrate }\end{array}$ & $\begin{array}{c}\text { It oxidizes or halogenates } \\
\text { proteins of the cell }\end{array}$ \\
\hline Quaternary compounds & Benzalkonium chlorides & $\begin{array}{l}\text { It decreases the } \\
\text { surface tension of cells }\end{array}$ \\
\hline
\end{tabular}

1. Certain studies suggest that wearing a mask can decrease the transmission of COVID-19 infection by $80 \%$ in healthcare workers and $47 \%$ in nonhealthcare workers.CDC recently declared that wearing cloth masks in the community setting is equally beneficial. As the demand for masks increased during pandemic availability of masks was a problem due to high demand and limited supply. The government should ensure that masks are easily accessible that too at a low cost to all. Masks should be supplied in rural areas. Various awareness methods should be used to sensitize the people on the importance of mask use, also its proper disposal. People should be made aware on how to wash their reusable masks also to timely throw away the disposable ones.Advertisements on television, radio and plays in the village should be conducted for explaining to people the proper use of mask like outer surface of the mask should not be touched, hands should be sanitized properly before and after wearing a mask. Cloth masks that can be made at home should be encouraged to people who do not have access to surgical masks (CDC 2020b). 
Social Distancing In Pandemic: Social distancing is the key to fighting this pandemic. the incidence of infection increases in highly crowded places as direct contact is the mode of transmission. with no full proof treatment modality, inability to create a vaccine in time, social distancing plays a critical role. It is recommended that minimum 6 feet distance should be maintained between individuals as droplet particles from sneeze can travel upto $1.5 \mathrm{~m}$ in distance.prediction model has been established by using big data of university of Washington and evaluation center. in this model disease transmission in 7 locked down cities were studied- Wuhan, Italy and Spain showed that social distancing reduced disease transmission effectively. Social distancing not only reduced the disease burden it also bought time for doctors to understand the disease pathology and treatment more efficiently hereby saving more lives (Song JY,et. al. 2020 and Qualls N, et. al. 2017).

Government of Inida and Social Distancing: The govt of India imposed a nationwide lockdown in the month of march, it continued till whole of Apriland June. this helped the healthcare workers to make a strategy for tackling this disease better. even though cases were slowly rising, the lockdown helped in flattening the curve. even after opening of the nation after lockdown few states that have a high concentration of coronavirus cases go into lockdown as and when needed. Public places like malls, cinema halls, restaurants, gyms etc remained close even after the lockdown ended. In states like Maharashtra meeting of more than 4 people had been banned. Social gatherings like marriage functions, funerals, big parties are avoided. special permission needs to be taken before these functions. a restriction of $20 / 50 / 100$ ( according to the rules of that region) people are put in these events. Reopening of shops and marketplaces have been closely controlled to avoid overcrowding. special precautions are taken like face masks are mandatory, use of hand sanitizers before entering the shops, thermal screening before entering has been started. strict action is taken against people who do not follow social distancing norms.

\section{Drawbacks-}

1. Negative impact on mental health- lockdown and social distancing reported an increased incidence of mental health problems like generalized anxiety disorder, insomnia , acute stress disorder, depression were noted (Brooks S.K.,et. al. 2020).

2. Impact on the economy- lockdown created a major dip in the economical growth of our country. Daily wage workers, small businessmen, artists etc suffered a major setback. The govt should aim to re empower the affected groups.

\begin{tabular}{|c|c|c|}
\hline People in specific places & Risk & Type of mask used \\
\hline $\begin{array}{l}\text { 1public crowded places eg hospitals, } \\
\text { supermarkets, restaurants etc }\end{array}$ & $\begin{array}{l}\text { a)high } \\
\text { b) middle to low }\end{array}$ & $\begin{array}{c}\text { a)surgical mask or respirator } \\
\text { b)disposable surgical mask or } \\
\text { medical mask }\end{array}$ \\
\hline $\begin{array}{l}\text { 2)suspected cases, confirmed cases, } \\
\text { asymptomatic carriers or close contacts }\end{array}$ & high & $\begin{array}{l}\text { surgical mask or } \\
\text { respirator without valve }\end{array}$ \\
\hline $\begin{array}{l}\text { 3)occupational exposed worker eg } \\
\text { emergency healthcare worker }\end{array}$ & $\begin{array}{l}\text { a)high to middle } \\
\text { b) low }\end{array}$ & $\begin{array}{l}\text { a)medical respirator } \\
\text { b) surgical mask }\end{array}$ \\
\hline 4) workers in ICU or wards of confirmed cases & a) high risk & medical respirator \\
\hline
\end{tabular}

Quarantine and Isolation: Quarantine means to separate and restrict the movement of those individuals who have been exposed to an infectious disease just to see if they become sick whereas isolation means separation of sick individuals who have already contracted the disease from the healthy ones. Quarantine and isolation are used to limit the spread of an infectious disease. It has been done in the past as well with diseases like Ebola etc. Outbreak of unknown etiology pneumonia in December 2019 has created a panic in the whole world. to stop the spread of corona virus quarantining of high risk individuals as proven to be effective. initially the disease was confined to the international travellers. as the incubation period of this disease is 14 days, all international travellers were quarantined for 14 days. this helped the doctors to treat the patient promptly and monitor their symptoms closely in the quarantine facilities.

This further prevented the community transmission of coronavirus disease. quarantine helps in controlling the pandemic systematically.In India all persons with history of international travel were compulsorily quarantined in government controlled facilities. Later as the disease outbreak progressed home quarantine had to be started. All the close contacts of a covid positive patient needs to be quarantined. Isolation of covid positive patients is mandatory. failure to do so may result in legal action. now individuals can be isolated at home or at a hospital. all covid hospitals have separate isolation wings. patients are closely monitored in these wards, only healthcare 
workers taking full precautions are allowed to go inside this facility. it is important to use social media wisely to communicate the importance of social distancing and quarantine.

Impact of Quarantine and Isolation: Quarantine and isolation deteriorates mental health in certain individuals it causes irritation, depression, anxiety and their mental health problemsthus proper counselling should be done for such individuals. It also causes financial loss and there is a lot of social stigma surrounding it. Managing mental health plays a key role during isolation or during quarantine. Individuals should be encouraged to follow a regular healthy routine, take balanced diet, exercise regularly, take up hobbies like drawing, painting etc. People should be asked to look for symptoms like fever, nausea, cough. provisions for ambulance and prompt health care services should be made for individuals in quarantine who start experiencing symptoms.

Technology A Boon to Mankind During Quarantine: With the advancement in technology the sense of loneliness experienced by people stuck alone has been minimised. social media platforms like whatsapp, facebook etc have helped people stay connected to their families. Social media has also been essential in creating awareness related to this pandemic. Apps like Arogya Setu app used in India enhances safety of the population, gives proper data about high risk areas. Also many apps have been used for hospital bed allocation and online drug supply during thispandemic (Giordano, G., et al 2020 and Shedev P. 2002).

Hydroxychloroquine As A Prophylactic Measure In Highly Exposed: Hydroxychloroquine is a drug widely used in India for malaria. with increase in covid 19 cases and with various ongoing research it has been found that antimalarials (chloroquine, hydroxychloroquine) have an antiviral action, research also suggests its use in chemoprophylaxis. In South Korea, an observational study conducted by Lee et al after after a mass exposure at an hospital, revealed promising results on giving hydroxychloroquine as a prophylactic drug to the exposed in quarantine (Lee S.H., et. al. 2020). On 22nd March 2020, hydroxychloroquine was recommended as a chemoprophylactic drug for COVID 19 infection by the Indian Council for medical research task force . the dose recommended - $400 \mathrm{mg} 2$ times a day on the 1st day which is followed by $400 \mathrm{mg}$ once a week for 7 weeks. This is given to health workers tending to SARS-COV-2 positive patients.

The use of drug should not be done without a proper medical recommendation by a doctor as it can cause serious side effects. Side effect of this medication includes (Pasaoglu I., et. al. 2019) -
1. allergic reaction to aminoquinolines

2. retinal toxicity

3. prolonged QT interval

4. increased risk for torsades de pointe

chemoprophylaxis against coronavirus infection has been started due to increasing number of doctors, nurses and various other health care workers are getting infected in our country.

Disinfection of Public Spaces During Pandemic: with a rise in number of covid positive patients and the opening of work places as well as public transport, routine sanitization of all public places and public transports like buses, trains, aeroplanes, restaurants and hotels need to be routinely sanitized. Studies show that SARS-COV can survive on various surfaces like plastic, glass, metal etc for a varying period of time depending on the type of surface. it can survive from hours to days therefore routine disinfection is mandatory, various dilutions of sodium hypochlorite solution has been used for this purpose. $0.1 \%$ sodium hypochlorite is used. this can be achieved through 1:50 dilution of bleach ie. five tablespoon bleach mixed in one gallon of water. As it is impossible to know the viral load of each surface, it is recommend to use it on surfaces that are very frequently touched. To prevent toxicity caused by this chemical, less skin contact is recommended. Also wherever the disinfectant is sprayed it should have a proper ventilation. The individual spraying should be wearing a protective gear covering skin nose eyes etc.

Ideally the sodium hypochlorite solution should be utilised within a month of its preparation, it should be stored in an opaque container which has a closed cap, preferably at room temperature (Kampf G., et. al. 2019 and Slaughter R.J.,et. al. 2019). Mechanism of action of bleach- its active ingredient $\mathrm{NaOCl}$, is a strong oxidising agent which kills bacteria and viruses. A number of related articles were reviewed (Adhit, K.K., et. al. 2020, Khatib, M.N., et. al. 2020, Gond, A.G., and R. Bhutada 2020, Gosavi, S., et. al. 2020 and Gulrandhe, P., et. al. 2020). Jilte and Deshpande reviewed the role of Rasayana (Jilte, A.A., and M.A. Deshpande 2020) whereas (Juneja et. al. 2020) reported on role of Vit. D in prevention of Covid-19. (Jachak et.al. 2020) reported about telerehabilitation in physiotherapy during pandemic and impact of COVID. Few of the related studies on preventive measures for spread of Covid were reviewed (Nibudey, et. al. 2020, Pasari, et. al. 2020, Pate, et. al. 2020, and Singh, et. al. 2020).

\section{CONCLUSION}

This is a review article on methods of prevention of transmission of coronavirus in the community. I have dealt with its modes of transmission ad how to prevent it 
using safety measure like use of hand sanitizers, covering your mouth and nose using a mask and following social distancing. As it is an emerging pathogen and not much is known about it the only way to be safe in this pandemic is through preventing the spread of infection. Scientists and doctors are working towards finding a vaccine and finding a definite treatment for this infection, For now the mainstay in fighting this pandemic remains prevention.

\section{ACKNOWLEDGEMENTS}

This work is partially supported by DMIMS and furthermore information is collected from various journals.

\section{Conflict of Interest: Nil.}

\section{Funding: DMIMS(DU), WARDHA}

Ethical Approved: From Institutional Ethical committee, DMIMS.

\section{REFERENCES}

Adhit, K.K., Ashish, P.A. and Siddhaarth, K., COVID19: A Review of Its Clinical Features, Effects on Gastrointestinal System and Possibility of Faecal Transmission. International Journal of Research in Pharmaceutical Sciences, 11, pp.623-27.

Barkema, H.W., Schukken, Y.H. and Zadoks, R.N., 2006. Invited review: The role of cow, pathogen, and treatment regimen in the therapeutic success of bovine Staphylococcus aureus mastitis. Journal of dairy science, 89(6), pp.1877-1895.CDC 2020b

Belser, J.A., Rota, P.A. and Tumpey, T.M., 2013. Ocular tropism of respiratory viruses. Microbiology and Molecular Biology Reviews, 77(1), pp.144-156.

Brooks, S.K., Webster, R.K., Smith, L.E., Woodland, L., Wessely, S., Greenberg, N. and Rubin, G.J., 2020. The psychological impact of quarantine and how to reduce it: rapid review of the evidence. The lancet, 395(10227), pp.912-920.

Cascella, M., Rajnik, M., Aleem, A., Dulebohn, S. and Di Napoli, R., 2021. Features, evaluation, and treatment of coronavirus (COVID-19). StatPearls.

Fan, Y., Zhao, K., Shi, Z.L. and Zhou, P., 2019. Bat coronaviruses in China. Viruses, 11(3), p.210.

Giordano, G., Blanchini, F., Bruno, R., Colaneri, P., Di Filippo, A., Di Matteo, A. and Colaneri, M., 2020. Modelling the COVID-19 epidemic and implementation of population-wide interventions in Italy. Nature medicine, 26(6), pp.855-860.

Gond, A.G. and Bhutada, R., 2020. Concept of dhoopana and its role in prevention of air born infection during covid-19 outbreak. International Journal of Research in Pharmaceutical Sciences, 11(Special Issue 1).

Gosavi, S., Shrivastav, S., Kamble, R. and Daigavane, P., 2020. The link between smoking and covid 19-a short review. International Journal of Research in Pharmaceutical Sciences, pp.931-933.

Gulrandhe, P., Sahu, A., Dandale, C., Naqvi, W.M., Phansopkar, P. and Kumar, K., 2020. Repercussions of mass gathering: Covid-19 pandemic. International Journal of Research in Pharmaceutical Sciences, 11(Special Issue 1).

Jachak, S.P., Phansopkar, P.A., Naqvi, W.M. and Kumar, K., 2020. Great Awakening--Telerehabilitation in Physiotherapy during Pandemic and Impact of COVID19. Journal of Evolution of Medical and Dental Sciences, 9(45), pp.3387-3394.

Jilte, A.A. and Deshpande, M.A., 2020. Role of rasayana (Kutipraveshik rasayana and achar rasayana) in the prevention of covid 19 like new diseases. International Journal of Research in Pharmaceutical Sciences, 11(Special Issue 1).

Juneja, S., Dangore-Khasbage, S. and Bhowate, R.R., Role of Vitamin D in Prevention of Corona Virus Infection (Covid-19). International Journal of Research in Pharmaceutical Sciences, 11, pp.407-10.

Kampf G., Todt D., Pfaender S., Kampf, G., Todt, D., Pfaender, S. and Steinmann, E., 2020. Persistence of coronaviruses on inanimate surfaces and their inactivation with biocidal agents. Journal of hospital infection, 104(3), pp.246-251.

Khatib, M.N., Gaidhane, S., Khatib, M., Ahmed, M., Gaidhane, A. and Syed, Z.Q., 2020. SARS-CoV and SARS-CoV-2: Similar viruses with different trajectories. Wutan Huatan Jisuan Jishu, 16(5).

Latchoumi, T.P., Ezhilarasi, T.P. and Balamurugan, K., 2019. Bio-inspired weighed quantum particle swarm optimization and smooth support vector machine ensembles for identification of abnormalities in medical data. SN Applied Sciences, 1(10), pp.1-10.

Lee, S.H., Son, H. and Peck, K.R., 2020. Can postexposure prophylaxis for COVID-19 be considered as an outbreak response strategy in long-term care hospitals?. International journal of antimicrobial agents, 55(6), p. 105988.

Li, W., Yang, Y., Liu, Z.H., Zhao, Y.J., Zhang, Q., Zhang, L., Cheung, T. and Xiang, Y.T., 2020. Progression of mental health services during the COVID-19 outbreak in China. International journal of biological sciences, 16(10), p.1732.

Mackowiak, P.A. and Sehdev, P.S., 2002. The origin of quarantine. Clinical Infectious Diseases, 35(9), pp.10711072. 
Nibudey, A.R., Baliga, V.S. and Dhadse, P.V., 2020. To Keep COVID-19 Out of Hospitals in India--Are We Prepared?. Journal of Evolution of Medical and Dental Sciences, 9(37), pp.2751-2755.

Pasaoglu, I. and Onmez, F.E., 2019. Macular toxicity after short-term hydroxychloroquine therapy. Indian journal of ophthalmology, 67(2), p.289.

Pasari, A.S., Bhawane, A., Balwani, M.R., Tolani, P., Ramteke, V. and Deshpande, N., 2020. Knowledge about COVID-19 and Practices among Hemodialysis Technicians in the COVID-19 Pandemic Era. International journal of nephrology, 2020.

Pate, B.S., Yeola, M.E., Gawande, A., Singh, A.K. and Tayade, H.A., 2020. Best Practices for Endoscopic Procedures in Covid-19 Pandemic. Journal of Evolution of Medical and Dental Sciences, 9(49), pp.3760-3767. Qualls, N., Levitt, A., Kanade, N., Wright-Jegede, N., Dopson, S., Biggerstaff, M., Reed, C., Uzicanin, A., Group, C.C.M.G.W., Group, C.C.M.G.W. and Levitt, A., 2017. Community mitigation guidelines to prevent pandemic influenza-United States, 2017. MMWR Recommendations and Reports, 66(1), p.1..

Responding to community spread of COVID-19 [online] Website https://www.who.int/ publications-detail/ responding-to-community-spread-ofcovid- 19. 2020. Slaughter, R.J., Watts, M., Vale, J.A., Grieve, J.R. and Schep, L.J., 2019. The clinical toxicology of sodium hypochlorite. Clinical toxicology, 57(5), pp.303-311.

Singh, K.T., Mishra, G., Shukla, A.K., Behera, S., Tiwari, A.K., Panigrahi, S. and Chhabra, K.G., 2020. Preparedness among dental professionals towards COVID-19 in India. The Pan African Medical Journal, 36.

Song, J.Y., Yun, J.G., Noh, J.Y., Cheong, H.J. and Kim, W.J., 2020. Covid-19 in South Korea-challenges of subclinical manifestations. New England Journal of Medicine, 382(19), pp.1858-1859.

Van Doremalen, N., Bushmaker, T., Morris, D.H., Holbrook, M.G., Gamble, A., Williamson, B.N., Tamin, A., Harcourt, J.L., Thornburg, N.J., Gerber, S.I. and Lloyd-Smith, J.0., 2020. Aerosol and surface stability of SARS-CoV-2 as compared with SARS-CoV-1. New England journal of medicine, 382(16), pp.1564-1567. Yeo, C., Kaushal, S. and Yeo, D., 2020. Enteric involvement of coronaviruses: is faecal-oral transmission of SARSCoV-2 possible?. The lancet Gastroenterology \& hepatology, 5(4), pp.335-337. 